\title{
ก่วกำ talentabijo
}

\section{MANAGEMENT OF NASOPHARYNGEAL CARCINOMA IN DR. ZAINOEL ABIDIN GENERAL HOSPITAL BANDA ACEH}

\author{
Fadhlial $^{*}$, Ferawati ${ }^{2}$, Irnawati ${ }^{2}$ \\ ${ }^{1}$ Medical staff of Oncology Division Department of Otorhinolaryngology Head and Neck Surgery Dr. Zainoel Abidin General Hospital \\ ${ }^{2}$ Otorhinolaryngology Head and Neck Surgery Residents of Otolaryngologist-Head and Neck surgery Departement of Dr. Zainoel Abidin General Hospital
}

\section{Abstract}

Introduction:Most of the patients who are at an advanced or final stage of an illness usually comes from middle to low economic level. Right now, nasopharyngeal carcinoma management in Dr. Zainoel Abidin General Hospital Banda Aceh only has chemotherapy to treat patients. Actually patients need to also undergo radiotherapy treatment which unavailable in our hospital yet, so we will refer it to another hospital located in North Sumatera or Jakarta. Therefore, the Acehnese government is preparing to build an oncology center which includes radiotherapy, so that we can treat our patients here.

Objective: The purpose of this research is to report management of NPC in Dr. Zainoel Abidin General Hospital Banda Aceh from January 2016 to October 2018.

Method: Data was taken from medical records of patients diagnosed with NPC from January 2016 to October 2018. 73 patients was diagnosed with NPC and underwent chemotherapy.

Result: There were 73 patients NPC, $44(60.3 \%)$ patients are male $(60.3 \%)$ and 29 patients are female $(39.7 \%)$. The youngest patient is 13 years old and the oldest is 79 years old. Most common average age are between 36 65 years old. The highest number is from Banda Aceh 10 patients. WHO histopathology classification reported that $26(35.6 \%)$ patients with type I and type III as well, and $21(28.8 \%)$ patients with type II. While $30(41,1 \%)$ patients underwent chemotherapy for 6 cycles, 43 (58.9\%) patients dropped out due to lack of living cost, long distance from hospital, or worsen of general condition.

Conclusion: It was reported 73 patients NPC, $44(60.3 \%)$ male and $29(39.7 \%)$ female. The youngest 13 years old and the oldest 79 years old. Most common average age between 36-65 years old. The highest number was from Banda Aceh 10 patients, WHO histopathology classification reported 26 (35.6\%) patients with type I and type III as well, and $21(28.8 \%)$ patients with type II. While $30(41.1 \%)$ patients underwent chemotherapy 6 cycles, $43(58.9 \%)$ patients dropped out due to lack of the cost of. This study reported $4(13.3 \%)$ patients who survived after underwent chemotherapy full dose with average range of 19-26 months.
\end{abstract}

\section{Article Info}

Keywords:

Nasopharyngeal carcinoma, Aceh, management

\section{*Corresponding author}

Address: Jl. Teuku Moh. Daud Beureueh No.108, Bandar Baru, Kec. Kuta Alam, Kota Banda Aceh, Aceh 24415

e-mail: yudiswife@gmail.com

\section{INTRODUCTION}

The Dr. Zainoel Abidin General Hospital, which is a referral and teaching hospital located in the center of Aceh that treats Head \& Neck cancer patients. All cases were histologically classified by standardized biopsy and staged according to the 2002 American Joint Committee on Cancer (AJCC) criteria using clinical assessment and CT scan work-up. The work-up of nasopharyngeal carcinoma includes a history, physical examination, nasopharyngeal examination and biopsy, dental evaluation, and appropriate diagnostic imaging studies (e.g., MRI and/or CT with contrast). These studies are important to determine the full extent of tumor in order to assign the stage appropriately and to design radiation ports that will encompass all the disease with appropriate doses. A chest X-ray should also be obtained. Chest CT should be considered for patients at high risk of or thoracic metastases. Imaging for distant metastases (i.e., chest, liver, bone) may include ultrasonography and/or CT. According to NCCN guidelines, modalities of management for NPC are radiotherapy, chemotherapy, and chemoradiotherapy.

We reported 73 patients registered between January 2016 to October 2018, we analyzed NPC cases treated at our hospital from which sufficient data were available. These reports include citizens who are not all permanent residents of Banda Aceh but also include patients who come from district hospitals. As a referral hospital, we treat patients not only from Banda Aceh and surrounding areas but also from other district and regions surround Banda Aceh. Some patients from more distant underdeveloped rural areas lacked long-term follow-up.

\subsection{Epidemiology and Etiology}

Nasopharyngeal carcinoma (NPC) is a malignant head and neck cancer, it differs from other head and neck cancers because of its unique characteristics in terms of epidemiology, etiology, clinical presentation, and prognostic factors $[1,2]$. It is a frequent cancer in Indonesia, with as the fourth most common tumor after cervical cancer, breast cancer, and skin cancer, and is the most common malignancy in the head and neck [3]. NPC is endemic in Southeast Asian countries ethnic
Chinese especially from the province of Guangdong province, where the incidence rates range from 30 to 50 in 100.000 patients [3-8]. NPC in the Western hemisphere (the Americas and Europe) is rare with an annual incidence of around 0.5/100,000, accounting for $1-2 \%$ of all head and neck cancers [9].

In North American whites its frequency is $0.25 \%$ of all cancers, while in American Chinese is $18 \%$. Chinese born in America have a lesser incidence than those born in China. One of the aetiologic factors of NPC frequently referred to is the consumption of salted fish. Dried salted fish, common in the Indonesian diet. This may be related to the carcinogenic compound, nitrosamine content, detected on the salted fish. The preservation process is thought to increase levels of carcinogenic nitrosamines. Burning of incense or wood (polycyclic hydrocarbon), use of preserved salted fish (nitrosamines) along with vitamin $\mathrm{C}$ deficient diet (vitamin $\mathrm{C}$ blocks nitrosification of amines and is thus protective) may be other factors operative in China [3, 10, 11].

Another etiologic of nasopharyngeal carcinoma is the Epstein Barr virus (EBV). It is associated with malignancies and has a characterized geographical distribution. In southern Chine, it is one of the major causes of morbidity and mortality. Despite the heavy public health burned of NPC in southern China and other endemic areas, relatively little is know about the etiology and prevention of NPC [11].

Chan et al. reported that the EBV genome is present in approximately $90 \%$ of NPCs observed in endemic regions, and is considered to play an important role in many aspects of NPC development. Interestingly, human papillomavirus infection has recently been identified in EBV-negative NPCs in non-endemic regions; however, the true biologic implications of these observations remain to be fully characterized [12].

Other environmental risk factors associated with NPC have also been identified, such as alcohol drinking and tobacco smoking, intake of chemical carcinogens, formalin and phorbol esters, occupational exposures, and some herbal medicines. Notably, a stronger association between tobacco smoking and NPC is observed in populations outside endemic regions than within high-risk populations. Concordantly, this occurs with differentiated versus undifferentiated or EBV-positive versus EBV-negative NPC [11,12]. 
In contrast, high consumption of fresh fruits and vegetables has been shown to decrease an individual's risk of NPC, which could be attributed to many components within these food products, such as fiber, vitamins, folate, and carotenoids. Although EBV is likely an early event in EBV-associated nasopharyngeal tumorigenesis, there is also mounting evidence suggesting that preexisting genetic abnormalities (e.g., loss of chromosomal regions on $3 p$ and $9 p$ ) may be required to support the persistent infection of premalignant or malignant epithelial cells of the nasopharynx $[11,12]$.

\subsection{Histopathology}

The World Health Organization (WHO) classifies NPC into three histopathological types based on the degree of differentiation. There have been many classifications proposed for nasopharyngeal carcinoma, and the World Health Organization (WHO) originally described three types according to histopathological in 1978. In practical terms, epidemiological and clinical features broadly define two groups, the squamous cell carcinomas (SCC) of varying degrees of differentiation and the undifferentiated carcinomas of nasopharyngeal type. The WHO type tumors are the most poorly defined with no clear morphological distinction between these and the undifferentiated carcinomas $[3,9,13]$.

Table 1. Histopathological classification of nasopharyngeal tumors [9]

\begin{tabular}{ll}
\hline \multicolumn{1}{c}{ WHO Classification } & \multicolumn{1}{c}{ Histopathological Classification } \\
\hline WHO type I & Keratinizing squamous cell carcinoma \\
WHO type II & Non-keratinizing (differentiated) carcinoma \\
WHO type III & Undifferentiated carcinoma \\
\hline
\end{tabular}

Type I, Squamous Cell Carcinoma (SCC), included those typical keratinizing sees with intercellular bridges, is seen in $5 \%-10 \%$ of cases of NPC and is characterized by well-differentiated cells that produce keratin and demonstrated the presence of intracellular bridges when observed under the electron microscope Type II included non-keratinizing epidermoid carcinomas, varies in cell differentiation (from mature to anaplastic cells) but does not produce keratin, but without definite squamous differentiation. Type III included undifferentiated carcinomas or poorly differentiated carcinoma. These cells have indistinct cell margins with hyperchromatic nuclei, is also non-keratinizing, but is less differentiated, with highly variable cell types (clear cell, spindle cell, anaplastic) [3, 13]. The histopathological around the world is different. In North America, around $25 \%$ of patients have a tumor with type I, $12 \%$ with type II, and $63 \%$ with type III. In southern Chinese $3 \%$ of patients with type I, $2 \%$ type II, and $95 \%$ type III $[3,13]$.

An alternative classification divided tumors into two histopathological types, namely, sees and undifferentiated carcinomas of the nasopharyngeal type (UCN'I's). This second classification took into consideration the correlation of the tumor with EBV serology. Patients with SCCs have a lower EBV titer, while those with UCN'I's have elevated titers. On clinical grounds, biopsies obtained from patients suffering from NPC sometimes show a mixed histopathological pattern. The recent WHO classification has taken this mixed pattern into account as well as the association of the EBV with type II and III tumors [3].

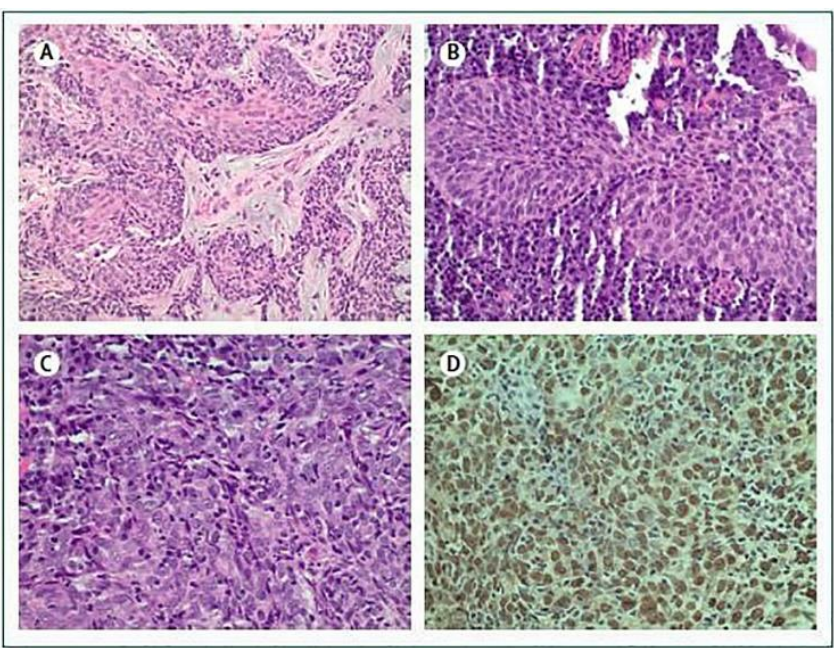

Picture 1. Light microscopic appearance of nasopharyngeal carcinoma [14]
(A) Keratinizing squamous cell carcinoma; hematoxylin and eosin (H\&E) stain, (B) Nonkeratinising carcinoma, differentiated subtype; H\&E stain, (C) Non-keratinizing carcinoma, undifferentiated subtype; H\&E stain, (D) Detection of Epstein-Barr virus-encoded small RNA by in-situ hybridization.

\section{MATERIAL AND METHODS}

This report was a descriptive study and the purpose of this study to reported patients diagnosed with nasopharyngeal carcinoma in the ORL-HNS department of Dr. Zainoel Abidin General Hospital Banda Aceh from January 2016 to October 2018. The sampling technique in this study used Consecutive Sampling. We classified criteria of patients according to gender, age, demographic, histopathological result and patients who underwent chemotherapy.

\section{RESULT}

It was reported 73 Nasopharyngeal Carcinoma patients who admitted to the ORL-HNS department of Dr. Zainoel Abidin General Hospital Banda Aceh from January 2016 to October 2018. Which were 35 patients in 2016, 24 patients in 2017 and 14 patients till October 2018. There were $44(60.3 \%)$ male and $29(39.7 \%)$ female for 3 years.

Graphic 1. Ratio male and female of nasopharyngeal carcinoma in Dr. Zainoel Abidin General Hospital Banda Aceh from January 2016 to October 2018.

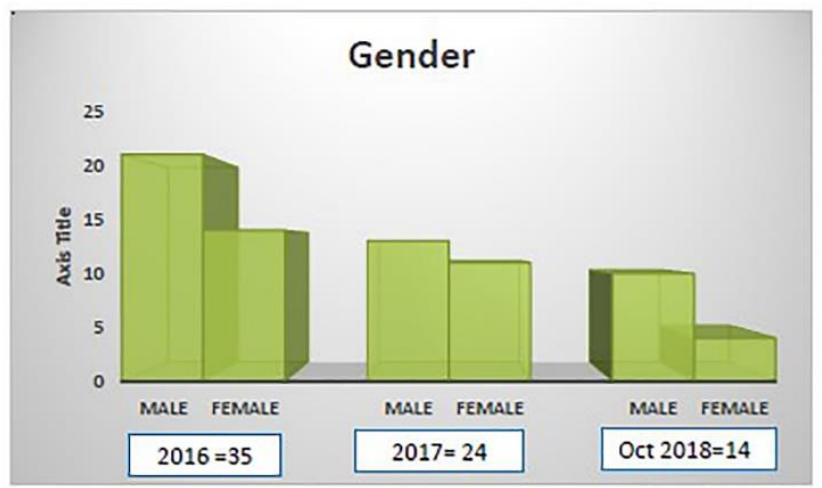

Distribution of age from 73 patients NPC, the youngest age 13 years old and the oldest 79 years old. Most common average age between 36-65 years old about 49 (67.4\%).

Graphic 2. Distribution of age of nasopharyngeal carcinoma in Dr. Zainoel Abidin General Hospital Banda Aceh from January 2016 to October 2018.

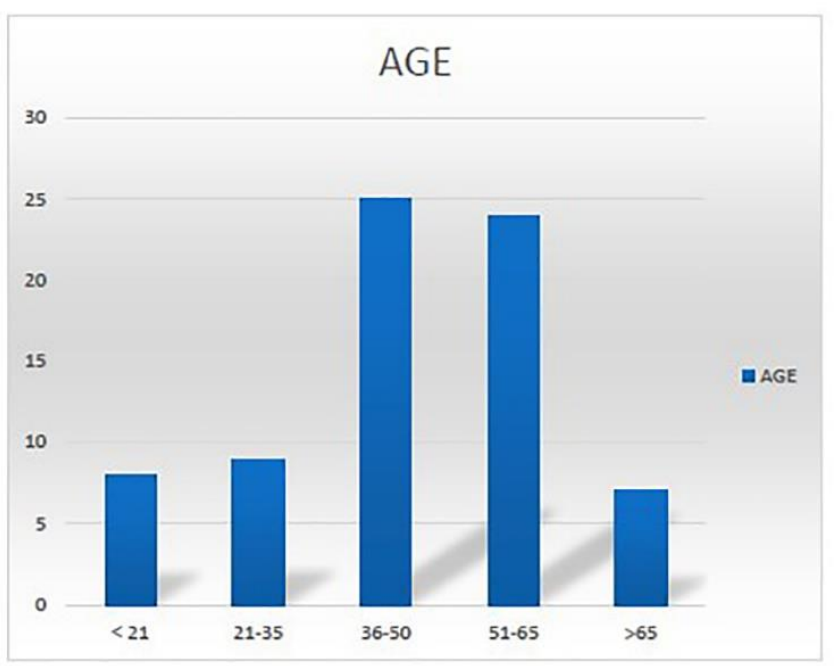

Distribution based on the region in Aceh province, from 73 Nasopharyngeal Carcinoma patients who came to the ORL-HNS department of Dr.Zainoel Abidin General Hospital Banda Aceh from January 2016 to October 2018, the highest number was from Banda Aceh $10(13.6 \%)$ patients, followed by Aceh Barat Daya 9 (12\%) patients. 
Graphic 3. Distribution of regional of nasopharyngeal carcinoma in Dr. Zainoel Abidin General Hospital Banda Aceh from January 2016 to October 2018.

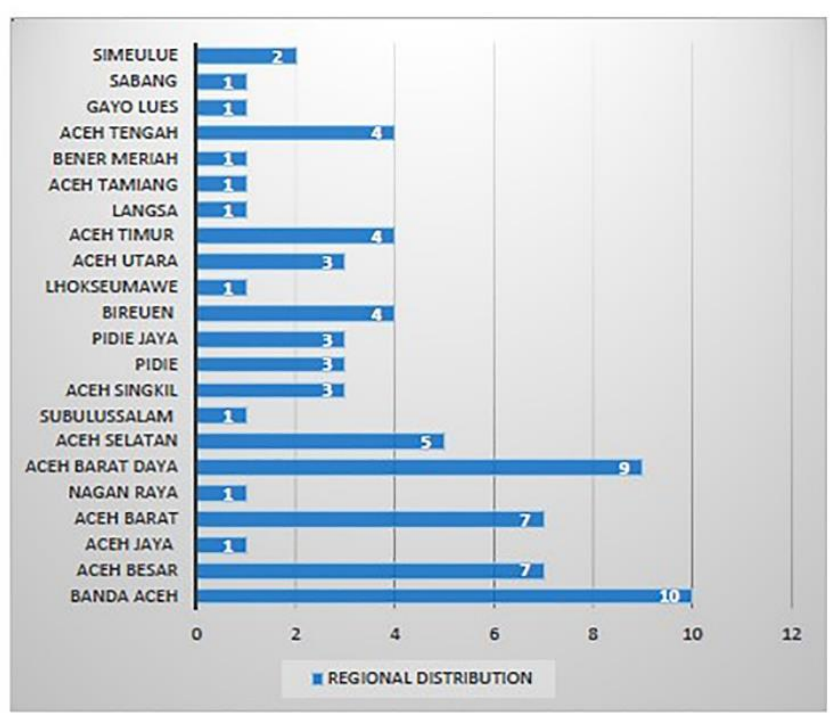

Based on histopathological WHO classification, we reported type I was $26(35.6 \%)$ patients as well as type III, and type II $21(28.8 \%)$ patients.

Graphic 4. Histopathological WHO classification of Nasopharyngeal Carcinoma in Dr. Zainoel Abidin General Hospital Banda Aceh from January 2016 to October 2018

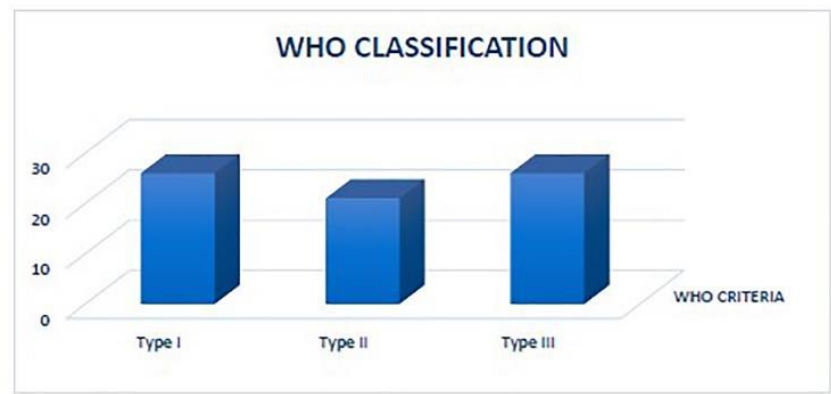

Seventy-three patients with Nasopharyngeal Carcinoma who admitted to the ORL-HNS department of Dr. Zainoel Abidin General Hospital Banda Aceh from January 2016 to October 2018. There were 30 (41.3\%) patient underwent chemotherapy for 6 cycles, $43(58.9 \%)$ patients who underwent incomplete chemotherapy.

Grapchic 5. Patients underwent chemotherapy of Nasopharyngeal Carcinoma in Dr. Zainoel Abidin General Hospital Banda Aceh from January 2016 to October 2018.

\section{Chemotherapy}

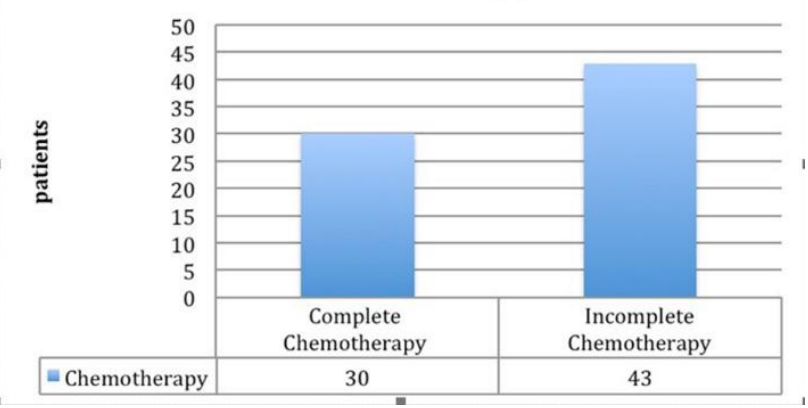

Table 2. Patients underwent chemotherapy of nasopharyngeal carcinoma in Dr. Zainoel Abidin General Hospital Banda Aceh from January 2016 to October 2018

\begin{tabular}{lc}
\hline \multicolumn{1}{c}{ Chemotherapy } & Amount \\
\hline Complete Chemotherapy & 30 \\
Incomplete Chemotherapy & 43 \\
\hline Total & $\mathbf{7 3}$ \\
\hline
\end{tabular}

From the 30 patients who had underwent 6 cycles of chemotherapy at Dr. Zainoel Abidin Hospital, 4 patients were in good condition and still being followed, 7 patients died and 4 patients who continued radiotherapy ( 1 patient died, 2 patients relapsed and one patient had no signs and symptoms of recurred until now), the rest of patients cannot be evaluated because they cannot be contacted.

\section{DISCUSSION}

In our study, the ratio of male and female was 1.5:1 (60.3\% male, $39.7 \%$ female). In Indonesia, Marlinda et al. reported a similar predominance, with $70.4 \%$ male and $29.6 \%$ female cases yielding a $2.4: 1$ ratio. In Indonesia NPC is the most frequent cancer in the head and neck and ranks as number 4 in males with the incidence of 6.2/100.000 [15]. The causes of the height of male sufferers than women in this cancer remain unclear. It might be men tend to be more often exposed to carcinogens in working environment compared to women, so more at risk for cancer [15]

Distribution of age the youngest age 13 years old and the oldest 79 years old. Most common average age between 36-60 years old. This distribution of age of patients diagnosed with NPC differs substantially in areas with various incidences. Zeng et al. reported that the incidence of NPC is increased with age, while in the endemic areas, obviously after 30-years, range at 40-59 years. It has also been reported the incidence of NPC has a relatively small peak among adolescents and young adults [13]. In another research, NPC patients from various countries are described with ages ranging from 4 to 91 years, with average ages at 50 to 60 years of age in Chinese populations. Marlinda et al. reported that the age distribution of NPC patients from Dr. Cipto Mangunkusumo Hospital Jakarta, had average ages at 40 to 49 years, and more than $80 \%$ of patients were diagnosed between 30 and 59 years of age [15].

From the distribution of region, The highest number was from Banda Aceh $10(13.6 \%)$ patients followed by Aceh Barat Daya $9(12 \%)$ patients. In terms of distance and transportation to the hospital, it is very reasonable if patients who came from Banda Aceh was the highest number because our general hospital is located in Banda Aceh, so patients no need more effort such as transportation and lack of living cost. Long distances and relatively difficult geographical conditions such as having to pass through mountains and seas, making it difficult for patients to come to the hospital. Aceh province has 23 districts which is located between 010 58' 37.2"-060 04' 33.6" North Latitude and 940 57' 57.6"- 980 17' 13.2" East Longitude with an average height of 125 meters above sea level. The borders of the Aceh Province, the North and East are bordered by the Malacca Strait, in the South with the Provinces of North Sumatra and the West with the Indonesian Ocean. Some patients who came from districts closer to North Sumatra, such as Eastern Aceh, Aceh Tamiang, Southeast Aceh and Singkil prefer to seek treatment in North Sumatra. Another people who come from regencies located on islands must travel by ship, patients from Sabang Island are more fortunate than those from Simeulu Island or Nasi Island, who have to travel more than one day from their place to Banda Aceh. The lowest number of patients from several districts does not necessarily indicate the actual conditions, many factors play a role including geographical problems. Further research is needed to look at ethnic relations with a high incidence of NPC in Aceh. Devi et al. reported that the highest recorded NPC incidence is found in the Bidayu people in Borneo Island (Kalimantan), with an age-adjusted incidence of 35/100.000 [16].

Histopathological WHO classification, the type I and type III was the same level at (35.6\%) which both were 26 patients, followed by type II (28.8\%) which were 21 patients. In Indonesia, Marlinda et al. reported which has an ethnically diverse population of 225 million patients, NPC is prevalent among different native patients and presents a major socioeconomic problem. Type III is most common, around $85.0 \%$ of cases proved to be undifferentiated carcinoma, and $12.7 \%$ WHO type I NPC tumors, only $2.3 \%$ of the cases were classified as WHO type II NPC tumors [15].

Based on NCCN guideline version 2.2018 for non-keratinizing or undifferentiated histology, consider testing for EBV in tumor and blood, for detecting EBV in pathologic specimens include in situ hybridization for EBV encoded RNA (EBER) or immunohistochemical staining for latent membrane protein (LMP). The EBV DNA load within the serum or plasma may be quantified using polymerase chain reaction (PCR) targetting genomic sequence of the EBV DNA such as BamHI-W, EBNA or LMP; these tests vary in their sensitivity. The EBV DNA load may reflect prognosis and change in response to therapy [17].

There is two options theraphy for Nasopharyngeal recurrent, unresectable or metastatic disease, its a First line theraphy and Subsequent line theraphy. Preferred regimen for first line teraphy is cisplatine or gimcetabine (category 1 ), theres also other recommended regimens for first line teraphy like a combination teraphy (cisplatin 
/5-FU, cisplatin or carboplatin/docetaxel, cisplatin or carboplatin/paclitaxel, carboplatin/cetuximab). Single agents (cisplatin, carboplatin, paclitaxel, docetaxel, 5FU, methotrexate, gemcitabine, capecitabine).

For the subsequent line theraphy, we can use combination therapy or single agents with option listed above for first-line therapy immunotherapy. Nivolumab can be used If previously treated, recurrent or metastatic non-keratinizing disease (category 2B), and Pembrolizumab if previously treated, PD-L1- positive recurrent or metastatic disease (category $2 \mathrm{~B}$ )

Table 3. NCCN Guideline

\begin{tabular}{|c|c|c|c|}
\hline \multicolumn{4}{|c|}{ Nasopharyngeal recurrent, unresectable or metastatic disease } \\
\hline & Preferred Regimens & $\begin{array}{l}\text { Other Recommended } \\
\text { Regimens }\end{array}$ & $\begin{array}{l}\text { Useful in certain } \\
\text { circumstances }\end{array}$ \\
\hline First-Line & $\begin{array}{l}\text { Cisplatin/gemcitabine } \\
\text { (category 1) }\end{array}$ & $\begin{array}{l}\text { Combination therapy } \\
\text { - Cisplatin/5-FU } \\
\text { - Cisplatin or carboplatin } \\
\text { /docetaxel } \\
\text { - Cisplatin or carboplatin } \\
\text { /pacitaxel } \\
\text { - Carboplatin/cetuximab } \\
\text { Single Agents } \\
\text { - Cisplatin } \\
\text { - Carboplatin } \\
\text { - Paclitaxel } \\
\text { - Docetaxel } \\
\text { - 5-FU } \\
\text { - Methotrexate } \\
\text { - Gemcitabine } \\
\text { - Capecitabine }\end{array}$ & None \\
\hline $\begin{array}{l}\text { Subsequent } \\
\text { Line }\end{array}$ & None & $\begin{array}{l}\text { Combination Therapy or } \\
\text { Single Agents } \\
\text { - See option listed above } \\
\text { for first-line therapy } \\
\text { immunotherapy } \\
\text { - Nivolumab if previously } \\
\text { treated, recurrent or } \\
\text { metastatic non- } \\
\text { keratinizing disease } \\
\text { (category 2B) } \\
\text { - Pembrolizumab if } \\
\text { previously treated, PD- } \\
\text { L1-positive recurrent or } \\
\text { metastatic disease } \\
\text { (category 2B) }\end{array}$ & None \\
\hline
\end{tabular}

However in our study from 73 patients, only 30 patients underwent chemotherapy 6 cycles, 43 patients dropped out. Usually, we use first-line regimen cisplatin+docetaxel. The thirty patients who had undergone 6 cycles chemotherapy at Dr. Zainoel Abidin Hospital are 4 patients still in good condition which are the first was a teenage 17 years old girl, was diagnosed as NPC stadium 4 with histopathology undifferentiated squamous cell carcinoma, underwent chemotherapy with regimen cisplatin+docetaxel full dose 6 cycles. The first cycle was on fifteen of June 2016 and finished on thirty of September 2016 Almost twenty-six months survived without radiotherapy, the second was a 50 years old man. He was diagnosed as NPC stadium 4 with histopathology undifferentiated squamous cell carcinoma who had undergone chemotherapy with regimen cisplatin + docetaxel full dose 6 cycles. The first cycle was on thirty of September 2016 and finished on eighteen of January 2017. Almost twentytwo months survived without radiotherapy, the third was a 22 years old girl. She was diagnosed as NPC stadium 4 with histopathology keratinizing squamous cell carcinoma who had undergone chemotherapy with regimen cisplatin+docetaxel full dose 6 cycles. The first cycle was on nine of June 2017 and finished on twenty-nine of April 2017. Almost nineteen months survived without radiotherapy, the last patient was a teenage 16 years old boy. He was diagnosed as NPC stadium 4 with histopathology non-keratinizing squamous cell carcinoma, underwent chemotherapy with regimen cisplatin+docetaxel full dose 6 cycles. The first cycle was on twenty-seven of April 2018 and finished on twenty of August 2018, during this time waiting for evaluating result as CT scan and histopathological as well after 3 months of chemotherapy.

Seven patients died which were with various condition such as acute/chronic renal failure, imbalance, and neutropenic fever. Four patients who continued underwent radiotherapy; 1 patient died because worsen condition during radiotherapy, 2 people relapsed after seven-month radiotherapy and 13 months after chemotherapy which signs and symptoms recurred as bloody rhinore and lumps in the neck. One patients had no signs and symptoms of recurred until now, the rest of patients (15 patients) can not be evaluated because they cannot be contacted.

According to NCCN guidelines the standard of therapy of NPC patients is radiotherapy alone or chemoradiotherapy or chemotherapy alone for advanced stage with distant metastasis. However, due to cost constraints, many patients refused to be referred to higher referral hospitals outside Aceh that provided radiotherapy because of the length of treatment and the amount of living costs incurred during chemoradiotherapy.

The frequency of distant metastasis is $4.4 \%$ to $7 \%$ at diagnosis and $20 \%$ to $27 \%$ during follow up [18]. In case of metastasis NPC (stadium IVC) only palliative treatment remain. In chemo-naive patients, platinum-based regimens are the first choice and give the best result [19]. Chen et al reported best response rates for palliative chemotherapy only were found with gemcitabine, capecitabine or docetaxel with a median survival of 9.5-15 months [20]. Apart from the poor outcome, combination chemotherapy in metastatic NPC in general result in increased toxicity [21].

NPC is more sensitive to radiotherapy and or chemotherapy than other head and neck cancers. The 5 years overall survival rates for stage I,II,III and IV diseases is $90 \%, 80 \%, 70 \%$ and $50 \%$ respectively $[22,23]$. The numbers below were published in 2010 in the 7th edition of the AJCC Cancer Staging Manual and are based on patients diagnosed between 1998 and 1999 [24].

Table 4. Relative 5-years survival rate

\begin{tabular}{cc}
\hline Stage & Relative 5-years survival rate \\
\hline I & $72 \%$ \\
II & $64 \%$ \\
III & $62 \%$ \\
IV & $38 \%$ \\
\hline
\end{tabular}

These survival rates for the patients who underwent chemoradiotherapy and only estimates-they can't predict what will happen to any individual.

\subsection{Limitations and future directions of study}

The limitation in our study is our hospital only have chemotherapy facilities, meanwhile patient with 4 th stage cancer according to NCCN guidelines need to be treated by chemoradition. Furthermore not all patients who has completed chemotherapy can be followed. There were four patients that had been followed after completed chemotherapy, which are observed no sign or symptom appearance within 19-26 months, which actually have to be observed for survival at least until 5 years.

\section{CONCLUSION}

It is important to optimize therapy according to the guidelines. The availability of a radiotherapy center plays a very important role in getting good outcome for nasopharyngeal carcinoma patients and will increase survival rate.

\section{REFERENCE}

[1] Yang Q, Zhao T-T, Qiang M-Y, Hu L, Lv X, Ye Y-F, et al. Concurrent Chemoradiotherapy versus Intensity-modulated Radiotherapy Alone for Elderly Nasopharyngeal Carcinoma Patients with Pre-treatment EpsteinBarr Virus DNA: A Cohort Study in an Endemic Area with Long-term Follow-up. Journal of Cancer. 2018;9(17):3023.

[2] Xu C, Sun R, Tang L-L, Chen L, Li W-F, Mao Y-P, et al. Role of sequential chemoradiotherapy in stage II and low-risk stage III-IV nasopharyngeal carcinoma in the era of intensity-modulated radiotherapy: A propensity score-matched analysis. Oral oncology. 2018;78:37-45.

[3] Bailey BJ, Johnson JT. Bailey's head and neck surgery-otolaryngology: Wolters Kluwer Health/Lippincott Williams \& Wilkins; 2014.

[4] Qiu W-Z, Peng X-S, Xia H-Q, Huang P-Y, Guo X, Cao K-J. A retrospective study comparing the outcomes and toxicities of intensity-modulated radiotherapy versus two-dimensional conventional radiotherapy for the treatment of children and adolescent nasopharyngeal carcinoma. Journal of cancer research and clinical oncology. 2017;143(8):1563-72.

[5] Chen W-H, Tang L-Q, Guo S-S, Chen Q-Y, Zhang L, Liu L-T, et al. Prognostic value of plasma Epstein-Barr virus DNA for local and regionally advanced nasopharyngeal carcinoma treated with cisplatinbased concurrent chemoradiotherapy in intensity-modulated radiotherapy era. Medicine. 2016;95(5).

[6] Chan AT, Hui EP, Ngan RK, Tung SY, Cheng AC, Ng WT, et al. Analysis of plasma Epstein-Barr virus DNA in nasopharyngeal cancer after chemoradiation to identify high-risk patients for adjuvant chemotherapy: a randomized controlled trial. Journal of Clinical Oncology. 2018;36(31):3091-100.

[7] Dada R, El Sayed M, Zekri J. Neoadjuvant Chemotherapy With Capecitabine Plus Cisplatin in Patients With Locally Advanced Nasopharyngeal Cancer: Case Series Study. Journal of global oncology. 2016;3(5):455-8.

[8] Lee A, Ma B, Ng WT, Chan A. Management of nasopharyngeal carcinoma: current practice and future perspective. J Clin Oncol. 2015;33(29):3356-64.

[9] Nutting CM, Cottrill CC, Wei WI. -Tumors of the Nasopharynx. Principles and Practice of Head and Neck Surgery and Oncology: CRC Press; 2009. p. 356-80.

[10] Dhingra P, Dhingra S. Diseases of Ear, Nose and Throat-E-Book: Elsevier Health Sciences; 2014. 
[11] Wu L, Li C, Pan L. Nasopharyngeal carcinoma: a review of current updates. Experimental and therapeutic medicine. 2018;15(4):3687-92.

[12] Bruce JP, Yip K, Bratman SV, Ito E, Liu F-F. Nasopharyngeal cancer molecular landscape. Journal of Clinical Oncology. 2015;33(29):3346-55.

[13] Zeng M-S, Zeng Y-X. Pathogenesis and etiology of nasopharyngeal carcinoma. Nasopharyngeal Cancer: Springer; 2010. p. 9-25.

[14] Chua ML, Wee JT, Hui EP, Chan AT. Nasopharyngeal carcinoma. The Lancet. 2015.

[15] Adham M, Kurniawan AN, Muhtadi AI, Roezin A, Hermani B, Gondhowiardjo $\mathrm{S}$, et al. Nasopharyngeal carcinoma in Indonesia: epidemiology, incidence, signs, and symptoms at presentation. Chinese journal of cancer. 2012;31(4):185.

[16] Devi BC, Pisani P, Tang TS, Parkin DM. High incidence of nasopharyngeal carcinoma in native people of Sarawak, Borneo Island. Cancer Epidemiology and Prevention Biomarkers. 2004;13(3):482-6.

[17] Network NCC. NCCN Clinical Practice Guidelines in Oncology (NCCN $®$ guidelines): head and neck cancers. Version 2.2018. 2018.

[18] Chan A, Teo P, Ngan R, Leung T, Lau W, Zee B, et al. Concurrent chemotherapy-radiotherapy compared with radiotherapy alone in locoregionally advanced nasopharyngeal carcinoma: progression-free survival analysis of a phase III randomized trial. Journal of clinical oncology. 2002;20(8):2038-44.

[19] Ali H, Al-Sarraf M. Chemotherapy in advanced nasopharyngeal cancer. Head \& Neck. 2000;14(8).

[20] Bensouda Y, Kaikani W, Ahbeddou N, Rahhali R, Jabri M, Mrabti H, et al. Treatment for metastatic nasopharyngeal carcinoma. European annals of otorhinolaryngology, head and neck diseases. 2011;128(2):79-85.

[21] Leong SS, Wee J, Tay MH, Toh CK, Tan SB, Thng CH, et al. Paclitaxel, carboplatin, and gemcitabine in metastatic nasopharyngeal carcinoma: a Phase II trial using a triplet combination. Cancer. 2005;103(3):569-75.

[22] Waldron J, Tin MM, Keller A, Lum C, Japp B, Sellmann S, et al. Limitation of conventional two dimensional radiation therapy planning in nasopharyngeal carcinoma. Radiotherapy and oncology. 2003;68(2):153-61.

[23] Cheng JCH, Chao KC, Low D. Comparison of intensity modulated radiation therapy (IMRT) treatment techniques for nasopharyngeal carcinoma. International journal of cancer. 2001;96(2):126-32.

[24] Society AC. Survival Rates for Nasopharyngeal Cancer - American Cancer Society. 2019. 